\title{
PENGEMBANGAN MOTIF BATIK SEMARANG UNTUK PENGUATAN IDENTITAS BUDAYA SEMARANG
}

\author{
Titiek Suliyati dan Dewi Yuliati
}

\author{
Departemen Sejarah, Fakultas Ilmu Budaya, \\ Universitas Diponegoro,Semarang-Indonesia
}

Alamat korespondensi: suliyati.titiek@gmail.com

Diterima/Received: 30 Oktober 2018; Direvisi/Revised: 13 Maret 2019; Disetujui/Accepted: 18 Maret 2019

\begin{abstract}
At the beginning of its development, Semarang Batik motifs did not reflect the special character of batik that developed in other regions. At that time, Semarang Batik tended to show coastal motifs and many were influenced by the Dutch and Chinese. This article highlights the development of Semarang Batik which helped shape the identity of the city of Semarang, moreover with the acknowledgement of UNESCO in 2006 which also had an impact on the development of batik motifs in each region, including Semarang. The contemporer Semarang Batik motifs are in the form of city and cultural icons, such as Tugu Muda, Blenduk Church, Marabunta Building, Blekok Srondol, Wewe Gombel, Warak Ngendok, and even food motifs such as Lumpia, Tahu Gimbal, and so on. Historical method was used in this study, includingheuristics (source collection), criticism, interpretation, and writing facts. The results of this study can be concluded that, the present Semarang batik motif developing metamorphosis from traditional motifs to contemporary ones with more varied innovations.
\end{abstract}

Keywords: Batik Semarang; Cultural Identity; Development Efforts.

\begin{abstract}
Abstrak
Pada awal perkembangannya, motif Batik Semarang belum mencerminkan ciri khas seperti batik-batik yang berkembang di daerah lain. Saat itu, Batik Semarang cenderung menunjukkan motif pesisiran dan banyak mendapat pengaruh dari Belanda dan Cina. Artikel ini menyoroti perkembangan Batik Semarang yang turut membentuk identitas kota Semarang. Apalagi dengan adanya penghargaan UNESCO pada 2006 turut berdampak pada pengembangan motif batik di masing-masing daerah, termasuk di Semarang. Motif Batik Semarang saat ini berupa ikon-ikon kota dan budaya Semarang, seperti Tugu Muda, Gereja Blenduk, Gedung Marabunta, Blekok Srondol, Wewe Gombel, Warak Ngendok, bahkan ada motif makanan seperti Lumpia, Tahu Gimbal, dan sebagainya. Artikel ini disusun dengan menggunakan metode sejarah, yang meliputi heuristik (pengumpulan sumber), kritik, interpretasi, dan penulisan fakta-fakta. Hasil penelitian ini dapat disimpulkan bahwa, motif batik Semarang yang saat ini berkembang merupakan metamorfosa dari motif tradisional ke kontemporer dengan inovasi yang lebih variatif.
\end{abstract}

Kata Kunci: Batik Semarang; Identitas Budaya Semarang; Upaya Pengembangan.

\section{PENDAHULUAN}

Batik di Indonesia sudah dikenal dan digunakan oleh wanita dan pria sejak berabad-abad yang lalu. Batik sangat lekat dengan kehidupan orang Jawa, Madura dan Sumatra. Batik tidak hanya dikenal di Indonesia, tetapi telah dikenal dan diakui oleh bangsa-bangsa lain. Walaupun demikian, asal-usul dan sejarah keberadaan batik di Indonesia masih menjadi perbincangan banyak ahli.

Kata batik memiliki kesamaan dengan kata "tik" yang artinya "titik". Kata "tik" ini berkembang artinya menjadi batik (Anas, 1997: 10). Ada juga yang menyebut, dalam bahasa Jawa kata batik berasal dari kata "amba" dan "nitik". "Amba" berarti menulis dan "nitik" artinya titik (Sularso, dkk., 2009: 23). 
Berdasar dua pengertian tersebut di atas tersebut, proses pembuatan motif kain dengan cara membuat titik-titik pada kain dengan menggunakan malam atau lilin batik cair. Alat yang digunakan untuk membuat titik-titik ini disebut canting. Proses ini membentuk motif yang terdiri atas susunan titik-titik dan goresan. Malam cair yang dilukiskan pada kain,berfungsi sebagai perintang atau penahan warna yang akan diproses selanjutnya (Soerjanto, 1982: 1).

Dari pengertian batik tersebut, ada dua hal yang yang terkait dengan batik, yaitu batik dalam pengertian proses pembuatannya dan batik sebagai kain yang memiliki motif yang spesifik. Batik sebagai hasil budaya masyarakat Indonesia memiliki keistimewaan dalam penciptaannya. Seni membatik mengandung nilai filosofi yang tinggi ketika para pencipta batik ini menciptakan motif-motif batik yang indah. Pada sehelai batik terkandung tiga unsur yang saling berkaitan, yaitu motif, fungsi dan filosofi.

Pencipta motif batik membuat kreasinya dengan berbagai maksud dan harapan yang baik, sesuai filosofi yang dihayatinya. Batik dengan berbagai motifnya memiliki fungsi dan aturan waktu penggunaannya.

Motif batik yang tercipta di masa lalu juga dapat menunjukkan status atau identitas sosial masyarakat, tingkat kepangkatan dan identitas kebangsawanan pada pemakainya. Sebagai contoh adalah batik Keraton yang khusus digunakan oleh keluarga keraton. Batik Keraton sering disebut sebagai batik Larangan yang tidak boleh dipakai oleh rakyat atau masyarakat biasa. Selain itu, ada juga batik Sudagaranyang dipakai oleh golongan saudagar atau pedagang serta batik Petani/rakyat yang dipakai petani dan masyarakat umum.

Keraton-keraton di Jawa terutama keraton di Surakarta dan Yogyakarta memiliki peranan sangat besar dalam mengembangkan dan mengangkat batik sebagai adi karya seni yang melengkapi busana dan upacara di lingkungannya (Kusrianto, 2013). Tidak dipungkiri, bahwa dari lingkungan keraton-keraton tersebut tercipta motif-motif batik yang memiliki nilai filosofi tinggi.

Pada zaman kolonial, produksi kerajinan termasuk batik merupakan produksi alternatif yang dikembangkan masyarakat sebagai sumber pendapatan di sela-sela waktu menunggu panen atau masa-masa paceklik (Soeroto,1983: 21). Selanjutnya ketika Politik Etis dijalankan di Indonesia, pemerintah kolonial memberikan perhatian pada industri-industri kecil masyarakat, termasuk batik sebagai alternatif mata pencaharian masyarakat akibat berkurangnya lahan pertanian yang menjadi salah satu sumber penghidupan masyarakat.

Industri-industri kecil yang dilakukan oleh masyarakat, termasuk batik saat itu hanyalah industri yang bertujuan untuk memenuhi kebutuhan sendiri. Industri-industri kecil ini, pada abad ke-20 berkembang pesat, sehingga dapat menunjang perekonomian pemerintah kolonial dan kesejahteraan masyarakat.

Industri batik merupakan industri rumahan dalam skala kecil.Sebagai industri rumahan, seluruh anggota keluarga biasanya terlibat dalam produksi batik ini (Maziyah, 2007: 11).Pada abad ke-20, batik mengalami perkembangan pesat. Karena batik yang memiliki landasan filosofi tinggi dalam penciptaannya dan sudah sangat lekat dalam kehidupan keseharian masyarakat Indonesia, maka sudah sewajarnya bila dunia mengakui nilai kultural batik yang sangat tinggi tersebut melalui penghargaan yang diberikan oleh UNESCO pada 2 Oktober 2009. Penghargaan ini terkait dengan Warisan Kemanusiaan untuk Budaya Lisan dan Nonbendawi (Masterpieces of the Oral and Intangible Heritage of Humanity). Dengan demikian dunia mengakui, bahwa batik menjadi salah satu identitas budaya Indonesia.

Identitas budaya saat ini menjadi penting, yang salah satu fungsinya adalah untuk menunjukkan ciri khas hasil budaya suatu bangsa. Secara sederhana yang dimaksud dengan identitas budaya adalah karakteristik atau ciri-ciri suatu kebudayaan yang lahir di lingkungan masyarakat yang berbedadengan karakteristik atau ciri-ciri kebudayaan masyarakat lain (Liliweri, 2003: 72). Identitas budaya adalah ciri budaya yang membedakan budaya suatu daerah dengan daerah lain, suatu bangsa dengan bangsa lain. Identitas budaya merupakan genuine culture yang menjadi penanda eksistensi suatu komunitas, masyarakat, atau lebih luas lagi penanda suatu bangsa. Tanpa identitas, suatu bangsa akan mengalami kesulitan ketika harus menunjukkan eksistensi diri di tengah-tengah pergaulan antarbangsa. 
Sejalan dengan pengakuan batik sebagai identitas budaya bangsa Indonesia, banyak daerah di Indonesia yang berlomba-lomba mengembangkan batik sebagai icon dan identitas daerahnya, tidak terkecuali Semarang.

Menurut Yuliati (2010), batik Semarang yang populer sebagai batik Semarangan memiliki motif khas yang merupakan benda-benda yang menjadi simbol-simbol (icon-icon) kota Semarang. Motif-motif batik Semarang yang berkembang saat ini dapat menjadi identitas kota yang memiliki akar budaya yang kuat. Batik Semarang dapat menjadi identitas budaya kota Semarang karena batik Semarang lahir sebagai hasil aktivitas budaya masyarakat Semarang yang memiliki nilai-nilai budaya yang tinggi dan dapat menjadi ciri khas kota Semarang. Untuk penguatan identitas kota Semarang ini perlu upaya untuk menggiatkan industri kerajinan Batik Semarang melalui pengembangan desain ragam hias dan motif-motif batik yang menonjolkan local wisdom Semarang. Untuk pencapaian tersebut perlu dilakukan penelitian untuk mendorong penguatan industri kerajinan batik Semarang, melalui pengembangan motif khas batik Semarang.

\section{METODE}

Artikel ini merupakan hasil penelitian yang disusun berdasarkan metode sejarah, meliputi heuristik,kritik, interpretasi, dan penulisan faktafakta (Gottschalk,1956:118-138).Proses pengumpulan data dalam penelitian ini dilakukan melalui beberapa teknik, yaitu observasi atau pengamatan, studi literatur, wawancara mendalam dan focusgroup discussion (FGD).

Observasi dilakukan di lingkungan komunitas para pengrajin batik dan pelaku usaha batik. Observasi bertujuan untuk melihat dan memahami aktivitas para perajin dan pengusaha batik serta memahami karakter dari masingmasing komunitas dalam memproduksi batik. Hasil observasi dapat menjadi dasar penelitian yang lebih mendalam.

Wawancara mendalam (in-depth interview) dengan beberapa pihak yaitu pengrajin batik, pengusaha batik dan masyarakat umum dengan menggunakan pedoman wawancara yang telah dipersiapkan sebelumnya. Pemilihan informasi pada tujuan dan sasaran penelitian.

FGD dilakukan terhadap pihak-pihak yang terlibat dalam industri Batik.FGD mendiskusikan berbagai hal yang berkaitan dengan dinamika dan upaya penguatan industri batik Semarang, pengembangan motif batik, upaya meningkatkan minat masyarakat terhadap batik Semarang dan upaya untuk menjadikan batik Semarang sebagai identitas budaya kota Semarang. Pengumpulan sumber juga dilakukan melalui penelusuran literatur, arsip, koran dan hasil-hasil penelitian yang dipublikasikan.

Setelah pengumpulan sumber proses selanjutnya adalah melakukan kritik sumber untuk memperoleh sumber atau data yang kredibel. Data-data yang telah diteliti kredibilitasnya, selanjutnya dihubungkan dalam susunan kronologis yang logis, disusun dalam hubungan sebab-akibat dalam bentuk tulisan yang disebut historiografi.

\section{AWAL MULA BATIK DI INDONESIA}

Banyak pendapat tentang awal mula keberadaan batik di Indonesia. Beberapa ahli berpendapat, bahwa seni membatik berasal dari India, Cina, Bangkok, Persi dan Turkestan Timur (Museum Jawa Tengah Ronggowarsito, 2004: 33). Ada pendapat yang mengatakan, wahwa batik Indonesia ada kemiripan dengan batik India, karena alat yang digunakan mirip, walaupun tidak sama persis.Alat yang digunakan untuk membuat kain bermotif di India menggunakan kuas yang disebut jegul (Susanto, 1973: 13). Selain itu, ada yang berpendapat seni batik berasal dari Cina, yang menghasilkan keramik dengan sistem batik yang menggunakan malam dan warna biru-putih (Sulaiman dalam Ayatrohaedi, 1986: 159).

Perdebatan tentang asal-usul batik sulit dihindari, karena seni batik terdapat hampir di semua penjuru dunia, kecuali Australia dan Asia Pasifik (Sulaiman dalam Ayatrohaedi, 1986: 196). Beberapa bukti yang menunjukkan, bahwa seni membatik merupakan budaya Indonesia. Beberapa di antaranya adalah Prasasti GulungGulung yang berangka $929 \mathrm{M}$, menyebutkan bahwa masyarakat Jawa saat itu telah melakukan kegiatan yang terkait dengan pembuatan batik, seperti wusu-wusu (menghilangkan biji kapas), 
anggumarang (menenun kain), mangragi (membuat motif pada kain), memukat mengkudu (mewarnai kain dengan akar mengkudu), manyula mengkudu (menyelup kain dengan akar mengkudu), mangubar (membuat warna terang atau menyolok).

Selain itu di Candi Ngrimbi di Jawa Timur terdapat arca Raden Wijaya (raja Majapahit) yang mengenakan kain dengan motif Kawung (Yuliati, 2010: 10).Menurut Toetti (2002: 1), motif Kawung dikenal sebagai motif Ceplok tertua. Motif Ceplok terdapat pada arca-arca candi Hindu, antara lain pada arca Ganesha dan arca Siwa Mahadewa

Serat Pararaton juga menyebutkan bahwa ketika pasukan Majapahit akan berperang menyerang Daha, Raden Wijaya membagikan kepada para prajuritnya kain bermotif Gringsing. Motif Gringsing dipercaya dapat menimbulkan semangat dan daya juang yang tinggi bagi pasukan Majapahit untuk memperoleh kemenangan (Hasanudin, 2001: 14). Motifbatik Gringsing yang berbentuk sisik ikan dengan titik hitam di tengahnya atau berupa kotak-kotak kecil dengan titik hitam di tengahnya merupakan motif batik tertua (Soedarso,1998: 111). Kata gring memiliki maknasakit dansing maknanya tidak. Jadi Gringsing bermakna "tidak sakit". Secara filosofis, Gringsing bermakna sebagai penolak bala (Hastangka, 2013 :205).

Berdasar pada pendapat para ahli dan buktibukti yang ditemukan tentang keberadaan batik di Indonesia, maka dapat dinyatakan, bahwa keberadaan batik di Indonesia sudah sangat lama, jauh sebelum masyarakat Indonesia berinteraksi dengan bangsa-bangsa lain.

\section{ASAL-USUL BATIK SEMARANG}

Dunia batik di Indoensia, tidak banyak menyebut nama Semarang. Nama-nama kota yang dikenal sebagai daerah pebatikyaitu terbagi atas daerah pedalaman dan daerah pesisir. Daerah pedalaman seperti Yogyakarta, Surakarta, Tulungagung, Ponorogo, Ciamis, Garut, Tasikmalaya, Purwokerto (Banyumas),Wonogiri, Kebumen, Purworejo, Klaten, Boyolali. Daerah pesisir seperti Pekalongan, Cirebon, Jakarta, Tegal, Indramayu,Sidoarjo, Mojokerto, Gersik, Lasem, dan Kudus(Susanto, 1973: 315). Demikian pula bila ada yang menyebut "Batik Semarang" atauBatik Semarangan",sulit menentukan ciricirinya. Hal ini berbeda dengan Batik Yogya, Batik Surakarta, Batik Lasem, Batik Pekalongan, Batik Cirebon atau Batik Bakaran (Pati), yang memiliki kekhasan masing-masing. Batik Semarang menurut para pakar batik, pemerhati batik, pengrajin dan pihak-pihak yang mempunyai perhatian terhadap batik, belum bisa menentukan motif khas batikSemarangan. Perdebatan dan diskusi mencari kesepakatan, apakah motif batik yang dibuat oleh wanita-wanita Indo-Eropa di Semarang dan produksi batik oleh orang Cina dapat disebut sebagai Batik Semarang. Bahkan, ada pendapat bahwa Semarang hanya sebagai tempat produksi batik saja, sedangkan motif yang dikembangkan oleh pengusaha batik Semarang masih mengacu ke motif batik pesisiran. Kondisi ini ironis dengan kondisi kota Semarang yang dari dulu sampai sekarang sebagai pusat aktivitas di berbagai bidang, terutama industri dan perdagangan termasuk industri batik. Berkaitan dengan perkembangan batik di Semarang, ada berbagai sumber yang dapat ditelusuri.

Sumber pertama adalah keberadaan Kampung Batik yang dapat dikaitkan dengan aktivitas membatik masyarakat Semarang. Kampung Batik diperkirakan keberadaannya sezaman dengan kampung bubakan, yang artinya membuka (bubak) lahan untuk pemukiman. Kampung batik juga disebut sezaman dengan kemunculan daerah Jurnatan, yang artinya juru nata (pejabat kerajaan) dan daerah-daerah lain yang memiliki toponim sesuai dengan mata pencaharian penduduk Semarang (Budiman, 1978: 6). Penamaan awal daerah-daerah tersebut diperkirakan pada masa pemerintahan Ki Ageng Pandan Arang I (Yuliati, 2010: 13).

Selanjutnya Maxwell (2003) menyebutkan bahwa ditemukan sebuah sarung batik buatan Semarang yang dibuat pada abad ke-19 dengan motif militer di Tropenmuseuril Amsterdam. Motif militer ini, menggambarkan barisan serdadu yang membawa bendera, pemain musik, dan para bangsawan mengendarai kuda. Demikian juga Asikin (2007) menyebutkan bahwa pada abad ke 19 diketahui ada 2 orang wanita Indo-Eropa yaitu Nyonya Ossterom \& Nyonya Fraquemont, yang mempunyai peran besar dalam sejarah batik di Semarang. Pada abad ke-19, Nyonya van 
Ossterom telah membuat batik dengan motif 59 tokoh-tokoh wayang, naga dan garuda

Selain kain batik, Nyonya van Ossterom juga membuat sarung dengan motif legenda Cina. Antara 1850-1860, muncul produksi sarung berkualitas bagus karya Carolina Josephina von Franquemont. Sarung produksi Carolina Josephina von Franquemont itu motifnya adalah kombinasi beberapa motif. Motif garis miring, diletakkan di bagian badan sarung, dibatasi motif ombak dengan isen-isen ikan. Badan sarung diberi motif ikan, kerang, kura-kura, tanaman air, kapal layar, dan seorang anak dengan mahkota naga di atas biduk.Papan dan tumpal sarung dihias dengan daun dan buah pohon eks.

Pada sumber yang lain, Pepin van Roojen (2001) menyebutkan,bahwa telah ditemukan beberapa jenis batik dan sarung yang dibuat pada akhir abad ke-19 di Semarang. Motif Bhuta dan sejenis daun pinus runcing asal Kashmir menghiasi sarung tersebut. Motif ceplok yang merupakan motif tua menghiasi badan sarung.

Di Semarang pada awal abad ke-20 berdiri perusahaan batik "Tan Kong Tien Batikkerij", milik orang Cina yang bernama Tan Kong Tien. Ayah Tan Kong Tien adalah Tan Siauw Liem, seorang tuan tanah kaya di Semarang dan sekaligus sebagai orang Cina yang mendapatkan gelar Mayor dari Pemerintah Hindia Belanda. Istri Tan Kong Tien adalah Raden Ayu Dinartiningsih yang merupakan kerabat Hamengku Buwana III dari Kesultanan Yogyakarta. Pegawai yang bekerja di perusahaan batik Tan Kong Tien dikategorikan dalam pekerjaan sebagaipembuat desain motif batik(carik), pembatik, dan tukang celup. Proses produksi batik dilakukan denganpola home industry, yaitu proses pembuatan batik dilakukan di masing-masing rumah pembatik yang tersebar di sekitar perusahaan batik Tan Kong Tien Batikkerj seperti kampung Rejo Sari, Kintelan, Kampung Batik, Karang Doro, Mlaten Trenggulun, Kampung Darat dan Layur (Yuliati, 2009: 39-40).

Dari Koloniaal Verslag 1919 dan 1925 yang dikutip oleh Yuliati (2009: 37), disebutkan bahwa, di Semarang antara 1019 sampai 1925, terjadi peningkatan yang pesat di sektor industri kerajinan batik, yaitu sebesar 82 industri batik. Pada 1919, tercatat hanya terdapat 25 industri dan pada 1925 terdapat 107 industri. Krisis ekonomi yang terjadi setelah Perang Dunia I, menyebabkan peningkatan industri batik, yang diakibatkan oleh impor tekstil dari India, Belanda, danInggris terhenti. Keprihatinan ini menyebabkan masyarakat berusaha secara mandiri memenuhi kebutuhan bahan sandang dengan membuat batik.

Produksi batik di Semarang mengalami kemunduran ketika masa penjajahan Jepang pada 1942. Ketika Jepang akan menduduki Semarang, atas permintaan Pemerintah Belanda, warga masyarakat melakukan pembakaran kampungkampung yang menjadi sentra industri dan tempat-tempat yang menjadi pusat perekonomian kota Semarang. Sasaran pembakaran adalah pusat-pusat perdagangan, toko-toko, gudanggudang pelabuhan dan lain sebagainya, dengan tujuan agar perekonomian kota Semarang tidak dapat dikuasai oleh pemerintahan Jepang (Brommer, dkk., 1995: 40-41).

Kampung Batik menjadi salah satu sasaran pembakaran. Kerusuhan selanjutnya terjadi ketika Jepang kalah dari sekutu dan harus meninggalkan Indonesia. Beberapa tentara Jepang terlibat bentrokan dengan pemuda Indonesia. Pertempuran yang berlansung lima hari, yaitu dari 15 sampai 19 Oktober 1945 ini dikenal sebagai Pertempuran Lima Hari. Akibat peristiwa ini, banyak kampung yang luluh-lantak akibat dari pembumihangusan kampung-kampung, termasuk Kampung Batik. Kehancuran kota Semarang berakibat pada terhentinya produksi batik di beberapa pabrik batik. Akibat kondisi yang tidak menguntungkan ini, masih tersisa beberapa perusahaan batik yang masih berproduksi, yang salah satunya adalah Tan Kong Tien Batikkerij. Tan Kong Tien Batikkerij masih berproduksi sampai 1970-an. Selanjutnya perusahaan ini mulai surut karena tidak ada generasi yang akan meneruskan usaha batik ini Yuliati (2009: 39).

Walaupun penjajahan Jepang di Indonesia meninggalkan trauma yang mendalam karena kekejamannya, tetapi ada hal yang positif dalam pengembangan motif batik di Indonesia. Keberadaan orang Jepang di Indonesia, terlepas sebagai bangsa penjajah, telah memunculkan motif batik hasil akulturasi budaya Jawa dan Jepang, yaitu batik Hokokai. Hokokai adalah nama organisasi propaganda pemuda yang dibentuk oleh pemerintah Jepang. Karena pada 
masa penjajahan Jepang adalah masa yang sulit dalam perekonomian, maka para pengusaha batik saat itu berusaha menghemat kain dalam pembuatan batik dengan cara membuat dua motif dalam selembar kain. Motif ini dikenal sebagai motif esuk-sore atau pagi-sore, yang dapat dipakai pada kesempatan yang berbeda.

Veldhuisen dan Heringa (1997) menyebutkan bahwa, ciri-ciri batik Hokokai adalah motifnya berbentuk buket bunga sakura, anggrek, dahlia, krisan, dan motif lunglungan, serta motif kupu-kupu, merak dan sebagainya. Motif ini menutupi seluruh kain. Motif batik Hohokai ini sudah muncul sebelum kedatangan Jepang, dalam motif Buketan Semarangan dipenuhi isen-isen. Motif-motif Cina dan Eropa lebih dominan dalam perkembangan batik Hokokai ini. Di Semarang pada 1950-an, masih ada perusahaan batik "ASACO" yang terletak di Jl. Senjoyo II No. 13 (Soekirno, 1956: 57). Tidak ada sumber yang dapat dilacak terkait keberadaan perusahaan ini pada 1950-an.

Pada 1952, masih tercatat beberapa perusahaan batik milik orang Cina dan Jawa di Semarang. Perusahaan-perusahaan batik tersebut antara lain: (1) Perusahaan Batik "Oei Tiong Djioe”, terletak di Jl. Mataram No. 235; (2) Perusahaan Batik "Tan Khoen Sioe", di Jl. Karangtempel 167; (3) Perusahaan Batik "Tan Ping Hoei”, di Jl.Widoharjo 33; (4) Perusahaan Batik "The Bik Liem", di Jl. Bulu No. 6; (5) Perusahaan Batik"Tjin San", di Jl. Poncol 180; (6) Perusahaan Batik "Trimargo", di Jl. Poncol 188; (7) N.V Batik Trading Coy di Purwodinatan Tengah No.18 (Petunjuk Telepon, 1952).

Sebagian besar perusahaan-perusahaan batik ini adalah milik orang Cina, hanya dua perusahaan batik yang dimiliki orang Jawa, yaitu Perusahaan Batik Trimargo dan N.V Batik Trading Coy. Melihat bahwa perusahaanperusahaan batik di Semarang pada masa lalu banyak dimiliki oleh orang Cina, maka tidak mengherankan bila batik Semarang motif dan coraknya sangat dipengaruhi oleh warna dan motif-motif Cina.

Setelah 1970-an, produksi batik di Semarang mulai menggeliat kembali. Ada beberapa pecinta batik yang berusaha menciptakan motif-motif baru yang merepresentasikan kondisi lingkungan, aktivitas, budaya dan cerita legenda masyarakat Semarang.

\section{PENELUSURAN MOTIF BATIK SEMARANG}

Pada masa pemerintahan kolonial Hindia Belanda, ada dua kategori batik, yaitu batik Kerajaan atau Keraton (batik Vorstenlanden) dan batik Pesisir. Pengertian Vorstenlanden adalah daerah kerajaan. Batik Keraton adalah batik yang diproduksi di wilayah kerajaan Kasunanan Surakarta (Solo) dan Kasultanan Yogyakarta. Batik Pesisir atau Pesisiran adalah batik yang diproduksi di luar wilayah keraton Surakarta dan Yogyakarta.

Batik Semarang dapat dikategorikan sebagai batik Pesisir atau batik Pesisiran, karena letak geografis Semarang di pesisir utara Jawa. Motif batik Semarang bersifat naturalistik dan realistik yang menggambarkan flora (bunga, pohon, daun) dan fauna (ikan, kupu-kupu, burung, ayam) serta bukit dan bangunan. Batik Pesisir memiliki kekhasan motif natural, yang mengekspresikan karakter masyarakat pesisir yang terbuka, bebas, dan lebih spontan. Sebaliknya, motif batik Keraton mengeksresikan simbolsimbol, aturan dan norma yang berlaku di keraton (Surakarta dan Yogjakarta).

Antara batik Keraton dan batik Pesisir ada beberapa perbedaan yaitu: (1) Batik Keraton memiliki warna dominan coklat, hitam,biru tua dan putih; (2) Motif batik Keraton sudah baku dan diciptakan sebagai simbol-simbol yang mengandung filosofi hidup; (3)Warna pada batik Pesisir lebih beragam dengan menggunakan warna-warna cerah, warna terang, dan mencolok; (4) Batik Pesisir memiliki motif yang lebih variatif dan natural. Motif yang sering ditampilkan berupa mahluk hidup seperti tumbuhan, hewan, manusia dan alam semesta seperti awan, air, laut dan gunung. Pembuatan motif tidak ada aturan baku, sehingga motif batik Pesisiran bebas mengadopsi motif-motif Cina dan Belanda, seperti motif burung hong, bunga peony, bunga krisant, naga, burung merak dan lain sebagainya.Pengaruh budaya bangsa-bangsa lain yang secara umum memperkaya motif batik Pesisiran adalah pengaruh budaya India, Belanda, Cina, Jepang. 
Kemunculan produksi batik dengan motif khas Belanda yang kemudian disebut sebagai batik Belanda pada 1840-1940, membawa dampak pada munculnya usaha pembuatan batik di Semarang. Batik Belanda adalah batik yang motifnya merupakan motif khas Belanda, yaitu motif yang mengambil tema legenda Little Red Riding Hood(Si Kecil Bertopi Merah), Snow White (Putri Salju) dan Hansel \& Gretel. Selain itu motif, batik Belanda berupa buketan (dari kata bouquet yang artinya bunga) yang dilengkapi dengan motif burung.

Perusahaan batik Belanda pertama didirikan oleh Carolina Josephina von Franquemont di Surabaya pada 1840. Perusahaan ini kemudian pindah ke kota Semarang.Mulanya batik Belanda hanya dibuat untuk konsumsi masyarakat Belanda dan Indo-Belanda. Semakin lama batik Belanda ini berkembang pesat karena konsumennyasemakin luas. Pada perkembangannya batik Belanda tidak hanya dipakai oleh masyarakat Belanda saja, tetapi juga dipakai oleh masyarakat diluar masyarakat Belanda, seperti orang Cina dan bangsawan Jawa. Saat itu daerah Pesisir Utara Jawa, seperti Pekalongan, Semarang dan sekitarnya menjadi tempat produksi batik Belanda (Doellah, 2002: 164).

Keberadaan pabrik Batik belanda di Semarang menginspirasi orang-orang Cina untuk membuat batik dengan motif yang sesuai dengan latar belakang budaya mereka. Motif batik yang diproduksi oleh orang-orang Cina memiliki ciri khas sendiri, seperti motif burung hong, naga, bunga peony, merak, dan burung.Batik Semarang atau Semarangan merupakan salah satu batik yang dipengaruhi motif-motif Belanda dan Cina.

Ciri-ciri batik Semarang yang mendasar adalah warnanya yang cerah, terang dan mencolok. Motif batik Semarangmengikuti kebebasan ide dan kreasi para penciptanya, sehingga penciptaan motif tidak mengikuti aturan-aturan yang baku. Tujuan utama penciptaan batik saat itu untuk keperluan pribadi, sehingga para pengrajin bebas berkreasi.

Batik Semarang secara umum motifnya tidak terlalu berbeda dengan motif batik di daerah pesisir Utara Jawa. Walaupun demikian ada ciriciri yang membedakan antara batik Semarang dengan batik dari daerah-darah pesisir Utara Jawa lainnya.
Menurut Heringa \& Harmen (1997) yang dikutip oleh Yuliati (2009: 42-43), yaitu bahwa batik Semarang memiliki ciri warna dasar oranye kemerahan. Batik Demak lebih menonjolkan warna dasar coklat muda, batik Kudus lebih menonjolkan warna dasar biru. Batik Semarang juga berbeda dengan batik Pekalongan, motifnya dominan berupa bunga, yang dirangkai dengan motif sulur dan lunglunan serta motif-motif Belanda. Motif Belanda saat itu menjadi motif favorit dalam produksi batik karena banyak orang Belanda yang membuka usaha batik di Pekalongan seperti L.Meetzelaar, Christina van Zuylen, Wollweber, dan J. Jans.

Berbeda dengan pernyataan diatas, Lee Chor Lin (2007:65) mengatakan, bahwa motif batik Lasem (Laseman) dengan latar dominan warna merah atau bangbangan memengaruhi motif batik yang diproduksi di pesisir utara Jawa, seperti Tuban, Surabaya dan Semarang.

Beberapa motif batik Semarang yang paling awal adalah sebagai berikut: (1) Motif merak dengan latar perbukitan dan anyaman bambu, yang diberi nama Merak Semawis oleh Dewi Yuliati selaku peneliti; 2) Motif kupu-kupu serta buket bunga cempaka dengan latar nitik. Warna latar dominan ungu. Motif batik ini diproduksi oleh Tan Kong Tien Batikkerij. Motif ini merupakan campuran antara motif batik Yogya dengan batik Semarang, yang telah dipengaruhi oleh motif Cina dan Belanda. Pengaruh motif batik Yogyakarta adalah motif "Nitik", pengaruh motif Cina adalah motif fauna (kupu-kupu), sedangkan pengaruh Belanda adalah motif buket bunga cempaka. Motif ini diberi nama Puspita Sari oleh Dewi Yuliati selaku peneliti; (3) Motif buket bunga cempaka dan kupu-kupu dengan latar kawung yang dipadu dengan parang rusak dan parang curigo. Motif ini merupakan campuran antara motif batik Yogya, motif batik Cina dan Belanda. Pengaruh motif batik Yogya adalah pada motif kawung, parang rusak dan parang curigo. Pengaruh motif Cina adalah motif fauna (kupu-kupu), dan pengaruh Belanda adalah motif buket bunga cempaka. Motif batik ini diproduksi Tan Kong Tien Batikkerij dan diberi nama Cempaka Rukmi oleh Dewi Yuliati selaku peneliti;(4)Motif kupu-kupu, buket bunga cempaka dengan latar grinsing. Motif batik ini diproduksi oleh Tan Kong Tien Batikkerij. Motif 
ini merupakan campuran antara motif batik Yogyakarta, motif batik Cina dan Belanda. Pengaruh motif batik Yogyakarta adalah motif gringsing. Pengaruh motif Cina adalah motif fauna (kupu-kupu), pengaruh Belanda adalah motif buket bunga cempaka. Motif ini diberi nama Grinsing Amengku Bumi oleh Dewi Yuliati selaku peneliti; (5) Motif Bang Biru (bang atau abang yaitu merah dan biru), yang berupa motif bunga dan hewan serta pinggiran bergelombang atau lengkungan memanjang dengan latar merah dan biru (Yuliati, 2009: 45-7).

\section{PERKEMBANGAN MOTIF BATIK SEMARANG}

Setelah produksi batik Semarang vakum cukup lama, pada 1970-an produksi batik Semarang mulai menggeliatdan memperlihatkan perkembangan motif-motifnya. Dapat dikatakan bahwa batik Semarang diproduksi pada 1970-an tersebut termasuk pada jenis batik modern.

Proses pembuatan batik modern tidak mengikuti aturan-aturan seperti pada proses pembuatan batik tradisional (Susanto, 1973: 15). Motif batik modern dapat berupa flora fauna, manusia dan benda-benda. Penciptaan motif batik modern lebih bebas dan tidak mengikuti normanorma dalam penciptaan desain motif batik tradisional. Penggunaan warna pada batik modern adalah warna-warna kontemporer dan menyolok. Pembuat batik tidak lagi menggunakan warna tradisional yang natural dan alami. Peralatan yang digunakan dalam pembuatan batik modern relativesama dengan penggunaan alat pada pembuatan batik tradisional, yaitu masih menggunakan canting dan cap.

Sebagai batik modern, motif batik Semarang berkembang pesat. Motif-motif batik Semarang pada awal 1970-an terinspirasi oleh aktivitas budaya, landmark kota Semarang, dan tokoh legendaris Semarang dan lain sebagainya. Motif-motif batik Semarang tersebut antara lain: (1) MotifWarak Ngendog (hasil budaya dan tradisi masyarakat Semarang) dan motif Pandan Arang (tokoh legendaris Semarang), yang diciptakan oleh Neni Asmarayani; (2) Motif Tugu Muda, Jembatan Mberok dan Pasar Ya'ik, yang diciptakan oleh Oentoeng Suwardi dan istrinya Tamsiyati, pemilik pabrik batik Sri Retno.
Setelah produksi batik Semarang vakum cukup lama, maka Umi. S. Adi Susilo pada 2005 berusaha membangkitkan kembali produksi batik Semarang. Untuk membangkitkan gairah dalam produksi batik Semarang, Umi melakukan pelatihan-pelatihanbatik. Ketika usahanya ini mulai menampakkan hasil, Umi membentuk perusahaan Batik Semarang 16. Usahanya ini telah membuahkan ratusan motif-motif baru. Motif ciptaannya tersebut terbagi dalam lima kategori, yaitu: (1) Motif yang menampilkan ikon, Semarang yaitu antara lain motif batik Tugu Muda, Gereja Blenduk, Lawang Sewu, Blekok Srondol, Jembatan Mberok, Warak Ngendhog dan Asem; (2) Motif yang menampilkan sejarah Semarang, yaitu antara lain motif Cheng Ho, Lawang Sewu, Gereja Blenduk dan Marabunta; (3) Motif yang menampilkan kuliner, yaitu antara lain batik motif Lumpia, motif Mie Kocok dan motif Tahu Gimbal; (4) Motif flora dan fauna yang mengangkat motif Merak Njeprak, Merak Mlerok Latar Asem, Cattleya, Kekiteran Sulur, Asem Remboko, Kukilo Asri, Asem Segoro, Bangau Pertiwi dan banyak lagi.

Umiselaluberusaha mengembangkan produksi batiknya dengan mengombinasikan motif klasik dan kontemporer. Hasil dari gabungan ini tercipta motif Parang Tugu Muda, Sido Roning Asem serta Motif Ceplok Cattleya. Motif batik ciptaan Umi saat ini ada 219 motif batik yang telah terdaftar di Ditjen HAKI. Upaya pengembangan motif batik dengan mengkombinasikan aneka macam motif yang indah dan dengan teknik pewarnaan alami, Umi S. Adi Susilo berhasil mengangkat kembali pamor batik khas Semarang.

Perkembangan batik Semarang dapat dikatakan terkait erat dengan upaya penegembangan Kampung Batik. Sebagai salah satu landmark dan ikon kota Semarang, Kampung Batik perlu mendapat perhatian dari para pemangku kebijakan dan masyarakat Semarang.

\section{PERKEMBANGAN KAMPUNG BATIK SEMARANG}

Kampung Batik sebagai kampung kuno, yang pembentukannya bersamaan dengan kota Semarang, nasibnya mengalami pasang surut. Pengembangan produksi batik di Kampung Batik 
sejak jaman Jepang sampai tahun 2000-an mengalami masa yang memprihatinkan. Walaupun pernah menjadi pusat kegiatan membatik di masa lalu, kondisi Kampung Batik setelah masa kemerdekaan tidak menunjukkan potensi di bidang produksi batik. Bahkan pada 1970-an, Kampung Batik dikenal sebagai kampung kumuh, tidak aman karena menjadi sarang kriminal dan selalu banjir. Pada waktu itu penduduk Kampung Batik belum banyak yang memproduksi batik.

Pada sekitar 1980, beberapa pengrajin batik yang ada di Kampung Batik berusaha membangkitkan kembali produksi batik Semarang. Usaha yang dirintis oleh para perajin batik ini mengalami kegagalan dan produksi batik Semarang kembali surut. Banyak hal yang menyebabkan kegagalan tersebut, di antaranya adalah para perajin batik kekurangan modal, keterampilan yang kurang dimiliki para pengrajin batik, kurangnya tenaga kerja, dan keterbatasan dalam manajemen.

Perubahan terjadi pada 2005, yaitu ketika ibu Sinto Sukawi, sebagai istri Walikota Semarang berkunjung ke Kampung Batik. Ia prihatin mengetahui ada Kampung Batik di Semarang, tetapi produksi batik Semarang sangat kurang. Untuk menghidupkan kembali produksi batik di Kampung Batik, maka pada 2005, Pemerintah Kota Semarang melalui Dewan Kerajinan Nasional Daerah (Dekranasda) mengadakan program pelatihan batik bagi masyarakat, terutama pada Usaha Kecil Menengah (UKM) batik. Pada program pelatihan batik tersebut Dekranasda meminta seorang pakar dalam pembuatan batik yaitu Marheno Jayanto dari Jakarta untuk memberikan pelatihan membatik.Dalam pelatihan tersebut, pihak pemerintah memberikan saran dan masukan kepada para peserta untuk berkreasi dan menggali inspirasi untuk menciptakan motif batik Semarang dari icon-icon kota Semarang yang sudah terkenal, seperti Lawang Sewu, Tugu Muda, Sam Po Kong, dan Warak Ngendhog. Motif-motif batik tersebut dapat dipadukan dengan motif flora dan fauna (sulur-suluran, alasalasan, bunga) yang telah menjadi dasar motif batik Semarang. Hasil perpaduan inilah yang diharapkan memunculkan motif baru yang akan dikenal oleh masyarakat sebagai motif batik khas Semarang atau batik Semarangan.

Setelah pelatihan dilakukan secara rutin selama kurang lebih empat tahun, masyarakat Kampung Batik banyak yang mulai menggeluti pekerjaan membatik. Banyak masyarakat Kampung Batik yang dulu bekerja serabutan dengan upah yang rendah, setelah mereka bekerja sebagai pembatik mendapatkan penghasilan yang memadai.

Perkembangan Kampung Batik semakin pesat setelah Pemerintah Kota Semarang menetapkan Peraturan Daerah (Perda) No. 14 Tahun 2011 Tentang Pembentukan Kampung Batik sebagai cagar budaya. Pada masa pemerintahan Walikota Hendrar Prihadi pada 2016 telah dicanangkan program Kampung Tematik. Kampung Tematik adalah suatu wilayah bermukim di bawah administrasi kelurahan yang menunjukkan jatidiri/identitas/makna atas suatu potensi masyarakat atau wilayah yang diangkat dan ditonjolkan atas hasil kesepakatan bersama. Maksud dari pembentukan Kampung Tematik adalah: (1) Menurunkan angka kemiskinan dan pengangguran; (2) Meningkatkan kualitas lingkungan permukiman; (3) Mengangkat kearifan lokal dalam mengelola potensi dan memecahkan permasalahan lingkungan; (4) Menambah tujuan atau destinasi wisata.

Melalui program Kampung tematik ini, maka nama Kampung Batik menjadi semakin populer tidak saja di lingkup Jawa Tengah, tetapi dikenal di seluruh Indonesia, bahkan manca negara. Sebagai Kampung Tematik Batik, tidak semua warga Kampung Batik bekerja sebagai pembatik. Walaupun Kampung Batik terdiri atas 2 (dua) Rukun Warga (RW) yaitu RW 01 dan RW 02, namun yang dikenal sebagai sentra batik, pusat kerajinan dan industri batik berada di RW 02. Hal ini tampak dari jumlah toko batik yang ada di RW 02, yaitu 14 toko dan pengrajin batik 7 keluarga. Toko batik yang ada di RW 02 antara lain: (1) Sanggar Cinta Batik Semarangan; (2) Batik Ngesti Pandowo; (3) Batik Handayani; (4) Batik Temawon; (5) Rumah Batik Kurnia; (6) Batik Rusyda Semarang; (6) Batik Balqis; (7) Sasono Batik Anggraini; (8) Batik Figa; (9) Batik Elly; (10) Batik Cinta; (11) Batik Laksmi Art; (12) Batik Nur Ayumi; (13) Batik Kinanti. 
Warga di RW 01 sama sekali tidak ada yang melakukan kegiatan membatik, dikarenakan minat masyarakat yang kurang dan SDM yang tidak banyak di wilayah RW 01. Warga di RW 01 ini sebagian besar adalah etnis Tionghoa (60\%) yang bekerja sebagai pedagang, sehingga tidak ada waktu dan minat untuk mempelajari cara membatik (Wawancara dengan Fauzi, ketua RW 01 Kampung Batik, 12 September 2018).

Walaupun di Kampung Batik ini terlihat banyak toko batik, namun sangat sedikit pengrajin yang sekaligus membuka show room batik yang besar.Salah satu pengrajin batik pemilik Sanggar Cinta Batik Semarangan adalah Eko Hariyanto dan Iin Windhi Indah Tjahjani. Produksi batiknya dilakukan di Kampung Batik Gedong No.430 RT 02 RW 02. Selain itu, ada Batik Figa, milik ibu Siti Afifah, yang berlokasi di Kampung Batik Malang 673 RT 02 RW 02.Perajin-perajin lain adalah perajin pemula atau hanya sebagai pedagang batik. Para perajin pemula yang usahanya kecil, bila mendapat pesanan besar, akan memesan batik dari tempat lain.

Produksi batik di Kampung batik ada berbagai jenis yaitu jenis batik tulis, batik cap dan batik colet(lukis) tergantung pasar yang meminatinya. Batik tulis adalah teknik membatik dengan menggunakan canting. Canting ini terbuat dari tembaga yang dibentuk khusus untuk menampung malam (lilin batik) yang ujungnya dibuat saluran/pipa kecil agar malam cair dapat keluar membentuk gambar awal pada permukaan kain. Batik tulis yang halus, motifnya tergambar pada dua sisi kain.

Motif (ragam hias) pada batik tulis tidak akan pernah sama bentuk dan ukurannya karena dibatik secara manual. Berbeda dengan batik cap yang kemungkinan motifnya sama persis antara motif yang satu dengan motif lainnya. Waktu yang dibutuhkan untuk pembuatan batik tulis relatif lebih lama ( 2 atau 3 kali lebih lama) dibandingkan dengan pembuatan batik cap. Pengerjaan batik tulis yang halus memakan waktu 1 hingga 3 bulan lamanya. Harga jual batik tulis relatif lebih mahal, dikarenakan dari sisi kualitas biasanya lebih bagus, mewah dan unik.

Batik cap adalah batik yang diproses dengan menggunakan cap, yaitu alat yang berupa stempel besar dari tembaga, dengan motif tertentu, berukuran $20 \mathrm{~cm}$ x $20 \mathrm{~cm}$. Batik colet atau batik lukis adalah teknik membuat batik yang menggunakan paduan canting dan kuas. Mengingat produksi batik semakin meningkat ditambah dengan munculnya toko-toko batik di Kampung batik, maka rumah-rumah menduduk selain dijadikan tempat tinggal, juga dijadikan tempat usaha, baik sebagai pabrik batik maupun sebagai toko batik

Kampung Batik merupakan salah satu kampung di Semarang yang sangat padat penduduknya. Sebagian besar lahan digunakan sebagai pemukiman, dan ada beberapa fasilitas baik sosial maupun fasilitas umum. Fasilitas sosial yang ada di Kampung Batik adalah Balai Batik, sumur dan toilet umum, masjid serta warungwarung milik warga. Fasilitas umum berupa jalanjalan kecil (gang), lahan terbuka untuk olah raga dan bermain.

Masyarakat yang menghuni Kampung Batik adalah masyarakat kelas menengah dan masyarakat kelas bawah. Kondisi ini menyebabkan tata ruang dan hunian tidak dibangun dengan konsep yang terencana. Ada beragam bangunan rumah hunian, ada yang berarsitektur modern dan ada juga rumah-rumah dengan arsitektur Jawa.

Motif-motif batik yang dihasilkan dari para pengrajin batik di Kampung Batik, selanjutnya diberi nama oleh Dewi Yuliati sebagai berikut: (1) Motif Merak Semawis. Motif ini merupakan motif batik Semarang yang diproduksi pada pertengahan abad ke-20 dan direproduksi oleh Batik Semarang Indah pada 2006; (2) Motif Banjaran Bagong, yang diproduksi oleh Batik Semarang Indah pada 2006;(3) Motif Merak Kusuma, yang diproduksi oleh perajin Batik Semarang Indah pada 2007; (4) Motif Merak Pertiwi dengan latar daun asam, bunga sepatu dan ombak, disesain (bersama Ngesti Lestri); (5) Motif Merak Puspa Rukmi, yang diproduksi oleh perajin Batik Semarang Indah pada 2007;(6) Motif Merak Kinasih, yang diproduksi oleh perajin Batik Semarang Indah pada 2007; (7) Motif Intan Puspita, yang diproduksi oleh Batik Semarang Indah pada 2007; (8) Motif Wora-wari Wigati. Wora-wari adalah bunga sepatu. Motif ini diproduksi oleh Batik Semarang Indah pada tahun 2007; (9) Motif Samodra Amengku Nagari, diproduksi oleh Batik Semarang Indah pada 2007 (Yuliati, $2009: 61-70$ ). 
Batik Semarang Indah merupakan salah satu perajin batik yang memproduksi Batik Semarang dengan motif-motif kontemporer. Walaupun demikian unsur-unsur batik Semarang yang awal (asli) tetap dipertahankan, seperti motif flora dan fauna khas Semarang dan warna-warna cerah yang dipengaruhi oleh budaya Cina.

\section{KAMPUNG BATIK DAN PENGEMBANGAN MOTIF BATIK SEMARANG}

Perkembangan motif batik Semarang yang telah dirintis sejak 1970-an, membawa dampak sosial bagi masyarakat Semarang. Motif batik Semarang yang mengangkat icon-icon dan landmark kota Semarang secara langsung maupun tidak langsung turut berperan dalam mengenalkan budaya dan kota Semarang pada masyarakat luas, tidak saja masyarakat Indonesia tetapi juga masyarakat manca negara.

Melalui pencarian yang sangat lama, Semarang telah memiliki produk batik dengan motif khas tersebut. Motif batik Semarangan tersebut menimbulkan kebanggaan terhadap produk lokal kita Semarang yang dapat dibanggakan. Selain itu, juga menimbulkan solidaritas sosial di antara para produsen, pengrajin dan masyarakat untuk bersatu dan bekerjasama dalam mengembangkan batik Semarangan.

Batik Semarang yang motifnya berbeda dengan motif-motif batik dari daerah/kota lain, diharapkan masyarakat memiliki kepedulian terhadap batik dengan cara menggunakan batik Semarang untuk semua keperluan, seperti busana, perlengkapan ibadah, dan perlengkapan rumah tangga. Kepedulian masyarakat terhadap batik Semarang hendaknya tidak hanya terbatas untuk penggunaan secara individu, tetapi juga hasil karya budaya yang perlu dijaga dan dilestarikan.

Dampak dari perkembangan Batik Semarang yang pesat dan sejalan dengan Perda No. 14 Tahun 2011 oleh Pemerintah Daerah tentang Pembentukan Kampung Batik sebagai cagar budaya, maka dalam kurun waktu yang tidak terlalu lama Kampung Batik Semarang mulai berbenah dan menata diri. Kondisi kampung Batik semakin membaik ketika pada masa pemerintahan Walikota Hendrar Prihadi. Sejak dicanangkan sebagai telah cagar budaya pada 2016, Kampung Tematik. Kampung Batik yang sebelumnya terkenal sebagai kampung kumuh, gelap dan tidak aman, berubah menjadi kampung yang bersih, aman dan tertata.

Kondisi Kampung Batik yang rapi menarik para wisatawan baik mancanegaramaupun domestik mengunjunginya. Para wisatawan tertarik untuk melihat proses pembuatan batik Semarang yang diproduksi di Kampung Batik ini. Batik yang diproduksi oleh para pengrajin di Kampung Batik juga mengembangkan motifmotif yang mendukung peguatan identitas Kota Semarang. Motif-motif tersebut terinspirasi dari bangunan-bangunan kuno, flora atau fauna, dan seni-budaya khas Semarang di antaranya adalah Gereja Blenduk, Blekok Srondol (Kuntul), Warak Ngendog. Kunjungan wisatawan ini tentu meningkatkan ekonomi masyarakat Kampung Batik.

Sejalan dengan naiknya pamor Kampung Batik, maka salah satu RT, yaitu RT 04 yang berupaya untuk lebih meningkatkan citra dan pomor Kampung Batik dengan cara menata wilayahnya menjadi Kampung Djadoel .

Kampung ini diberi nama Djadoel yang merupakan singkatan dari kata "djaman doeloe". Kampoeng Djadoel berbeda dengan Kampung Tematik Kampung Batik yang telah lebih dulu dikenal oleh masyarakat, karena konsep utama Kampoeng Djadoel tidak pada produksi batik, tetapi pada upaya mengenalkan akar budaya Jawa dan Semarang di masa lalu kepada masyarakat.

Kemunculan Kampoeng Jadoel pada 2016 sejalan dengan maraknya Kampung Tematik di Semarang. Para warga RT 04 RW 02 Kampung Batik berinisiatif untuk membenahi lingkungan kampungnya. Salah satu cara pembenahan kampung adalah dengan membuat mural di tembok-tembok rumah warga dan mengecat jalan kampung. Mural utama dibuat dengan tema Sejarah Kota Semarang, dimulai dari cerita awal pemerintahan kerajaan Mataram kuno, hingga berdirinya kota Semarang oleh Ki Ageng Pandanaran. Ki Ageng Pandanaran datang dan membuka lahan di Pulau Tirang dan daerah Bubakan, yang digambarkan di daerah tersebut banyak pohon asam yang tumbuhnya jarang. Gambaran daerah ini menjadi asal usul nama kota Semarang, yaitu daerah yang ada pohon asem arang (jarang). Selanjutnya digambarkan pula Ki Ageng Pandanaran menjadi bupati 
Semarang. Mural juga memggambarkan proses islamisasi di Semarang dan kedatangan Laksmana Cheng Ho yang membuat pemukiman di sekitar Gedong Batu. Kemudian dilanjutkan dengan gambar proses penjajahan Pemerintah Kolonial Belanda dan VOC, jaman penjajahan Jepang sampai masa kemerdekaan Indonesa. Mural dibuat seperti model Wayang Beber dan digabungkan dengan lukisan batik yang artistik. Mural ini dibuat setinggi kurang lebih 2 meter dan panjang 46 meter. Selain mural utama juga dibuat mural-mural dengan motif batik, pemandangan alam maupun hiasan flora \& fauna di tembok-tembok rumah penduduk.

Kondisi Kampoeng Djadoel yang semakin rapi dan tertata mengundang banyak wisatawan domestik maupun manca negara mengunjugi kampung tersebut. Untuk menambah daya tarik Kampoeng Jadoel, Ketua RT 04 RW 02, bapak Dwi Christianto beserta Sekretaris RT 04 RW 02, bapak Luwiyanto beserta masyarakat membuat prakarsa untuk menyediakan batik hasil produksi Kampung Batik dan daerah-daerah lain dijual di sini (Wawancara dengan Luwiyanto, 19 Oktober 2018). Selain itu juga disediakan pakaian-pakaian tradisional serta sepeda kuno, yang disewakan untuk berfoto. Juga ada makanan khas kota Semarang yang dijual di Kampoeng Djadoel. Bahkan ketika ada pengunjung di Kampoeng Jadoel, disambut dengan musik dan lagu Tempo Dulu.

Kampoeng Jadoel saat ini menjadi destinasi wisata tidak hanya masyarakat Semarang, tetapi masyarakat di luar Semarang dan manca negara. Hal ini membawa perubahan yaitu Kampoeng Djadoel menjadi kampung yang asri, bersih dan aman. Kondisi kumuh, gelap dan tidak aman sudah tidak tampak lagi.

Dengan demikian pengembangan motif batik Semarang telah berperan dalam meningkatkan produksi batik. Produksi batik Semarang meningkat membawa dampak yang baik pada pengembangan Kampung Batik dan Kampung Djadoel. Upaya dan kerja keras warga Semarang dalam hal ini warga Kampung Batik dan Kampung Djadoel perlu mendapat apresiasi. Dengan caranya masing-masing mereka berusaha menampilkan eksistensi dan identitasnya sebagai warga Semarang yang baik.

\section{SIMPULAN}

Batik Semarang walaupun memiliki akar sejarah panjang, baru di abad ke-20 menampakkan motif yang dianggap sebagai motif batik Semarang. Perdebatan panjang tentang motif batik Semarang, yang ditengarai mendapat pengaruh dari motif Cina dan Belanda sudah mulai surut ketika para seniman dan produsen batik pada 1970-an mulai mencari motif-motif khas Semarang.

Pengakuan dan penghargaan UNESCO terhadap batik Indonesia sebagai Warisan Kemanusiaan untuk Budaya Lisan dan Nonbendawi (Masterpieces of the Oral and Intangible Heritage of Humanity) pada 2 Oktober 2009 mendorong masyarakat dari berbagai daerah atau kota untuk mencari ciri khas motif batik, tidak terkecuali Semarang.Upaya berbagai pihak baik para perajin batik, pemerintah dan warga masyarakat Semarang dalam mengembangkan motif batik Semarang telah membuahkan hasil dan efek positif, yaitu meningkatkan destinasi wisata budaya kampung tematik Kampung Batik dan Kampung Djadoel.

Pemerintah Kota Semarang memiliki kewenangan penuh dalam pengelolaan Kampung Batik. Walaupun demikian,dalam peran masyarakat berswadaya membangun fisik, lingkungan (sosial dan budaya) Kampung Batik lebih besar. Dinamika dalam pencarian motif Batik Semarang dan upaya pengembangannya diharapkan dapat terus berlanjut untuk mempertahankan dan semakin memperkuat identitas budaya kota Semarang.

Manajemen produksi batik Semarang yang meliputi sistem produksi, promosi dan pemasaran diharapkan dapat terus disempurnakan secara profesional. Batik Semarang yang menjadi salah satu identitas Semarang diharap-kan dapat memperkuat identitas nasional di kancah pergaulan global.

\section{REFERENSI}

\author{
Anas, Biranul (1997). Indonesia Indah "Batik" \\ Buku ke-8. Jakarta: Yayasan Harapan Kita, \\ BP3 Taman Mini Indonesia Indah.
}


Asikin, Saroni (2007), Ungkapan Batik Di Semarang: Motif Batik Semarang. Semarang: Citra Prima Nusantara.

Ayatrohaedi (1986). Kepribadian Budaya Bangsa (Local Genius). Jakarta: Pustaka Jaya.

Biranul A. (1997). Indonesia Indah seri Batik. Jakarta : Yayasan Harapan Kita.

Brommer, dkk. (1995). Semarang Beeld van Een Stad. Plumerend: Asia Maior.

Budiman, A. (1978). Semarang riwayatmu Dulu. Semarang: Penerbit Tanjung Sari.

Doellah, H. Santosa (2002). Batik : Pengaruh Zaman dan Lingkungan. Surakarta: Danar Hadi.

Goottschalk, Louis (1975). Mengerti Sejarah: Pengantar Metode Sejarah. Jakarta: Yayasan Penerbit Universitas Indonesia.

Gottschalk, Louis (1958). Understanding History. A Primer of Historical Method. New York: Alfred A.Knoft.

Hasanudin (2001). Batik Pesisiran: Melacak Pengarus Etos Dagang SantriPada Ragam Hias Batik. Bandung: Kiblat Buku Utama

Hastangka (2013). "Ontologi Batik: Melacak Dimensi Metafisis Batik Klasik Jawa”. Jurnal Filsafat, Vol. 23 (3): 199-214.

Heringa, R. dan Harmen C. Veldhuisen (1997). Batik From the North Coast of Java. Los Angeles: Los Angeles County Museum of Art.

Kusrianto, Adi (2013). Batik Filosofi, Motif \& Kegunaan. Yogyakarta: CV Andi Offset.

Lee Chor Lin (2007) Batik: Creating an Identity. Singapura: National Museum of Singapore

Liliweri, Alo (2003). Makna Budaya dalam Komunikasi Antar Budaya. Yogyakarta: LKIS.

Maxwell, R. (2003). Textiles of Southest Asia: Tradition, Trade, and Transformation. Canberra: National Gallery.

Maziyah, S. (2007). "Korelasi Antara Proses Produksi Batik Dengan Pemberdayaan Perempuan”. Citra Lekha, Vol. 11 (1): 1121.

Museum Jawa Tengah Ronggowarsito (2004). Gaya Ragam Hias Batik: Tinjauan Makna dan Simbol. Semarang: Museum Jawa Tengah Ronggowarsito.
Riyanto, Didik (1995). Proses Batik Tulis, Batik Cap dan Batik Printing. Solo: Aneka Solo.

Roojen, Pepin van (2001). Batik Design. Amsterdam: The Pepin Press.

Sewan, Susanto (1973). Seni Kerajinan Batik Indonesia. Yogyakarta: Balai Penelitian Batik dan Kerajinan, Lembaga Penelitian dan Pendidikan Industri, Departemen Perindustrian.

Soedarso (1998). Tinjauan Seni: Sebuah Pengantar untuk Apresiasi Seni. Yogyakarta: Suku Dayar Sana.

Soekirno (1956). Semarang. Semarang: Djawatan Penerang Kota Besar Semarang.

Soerjanto (1982). Sejarah Perkembangan Batik. Yogyakarta: Balai Besar Penelitian dan Pengembangan Industri Kerajinan dan Batik.

Soeroto, Soeri (1983). "Sejarah Kerajinan Indonesia”. Prisma, No.8.

Sularso (2009). 60 Tahun Gabungan Koperasi Batik Indonesia. Jakarta: Koperasi Pusat

Toetti (2002). "Uraian Singkat Motif Batik Garis Miring” dalam Batik Hias Parang dan Lereng, PPBI Sekar Jagad, Yogyakarta.

Wahono (2004). Gaya Ragam Hias Batik: Tinjauan Makna dan Symbol. Semarang: Pemerintah Provinsi Jawa Tengah, Dinas Pendidikan dan Kebudayaan, Museum Jawa Tengah Ronggowarsito.

Yuliati, Dewi (2009). Mengungkap Sejarah dan Motif Batik Semarang. Semarang: Universitas Diponegoro Press.

Yuliati, Dewi (2010). "Mengungkap Sejarah dan Motif Batik Semarangan”. Paramita: Journal of Historcal Studies, Vol. 20 (1): 11-20.

\section{DAFTAR INFORMAN}

Wawancara dengan Fauzi, ketua RW 01 Kampung Batik, 12 September 2018

Wawancara dengan Luwiyanto, pengusaha batik di Kampung Batik, 19 Oktober 2018. 